\title{
Analisis Balance of Interest dalam Studi Kasus Kepentingan Turki Melakukan Kerja Sama dengan Rusia di Suriah pada 2016 - 2019
}

\author{
Andini Anissa \\ Pascasarjana Ilmu Hubungan Internasional, Fakultas Ilmu Sosial dan Ilmu Politik, Universitas \\ Indonesia - Indonesia \\ Email: andini.anissa@ui.ac.id
}

\begin{abstract}
When the Arab Spring swept through the Arab world as far as Syria, Turkey and Russia were not on the same side. Turkey demand a regime change, while Russia supports the regime. The relationship between the two countries was also exacerbated by the downing of the Sukhoi-24 jet which led Russia to impose a number of sanctions on Turkey. However, from 2016 to 2019, the relationship between the two has started to improve. This was marked by various cooperation to end the civil war in Syria. Based on the theory of balance of power, Turkey should balance against Russia because every country always try to prevent one country from dominating. Instead they both cooperate. The military intervention carried out by Russia in Syria in 2015 can be analysed as an attempt to change the global balance of power, while Turkey can be categorized as a regional rising power. This article tries to answer: why Turkey choose to cooperate with Russia in Syria? I argue that the change in the Turkey's foreign policy during the AKP's increasingly harsher against the Kurds. This caused friction with the US, so that Turkey establish strategic relations with Russia to fight Kurdish in Syria.
\end{abstract}

Keywords: Turkey, Russia, Balance of Interest, Foreign Policy

\begin{abstract}
Abstrak
Ketika Musim Semi Arab melanda dunia Arab hingga ke Suriah, Turki dan Rusia tidak berada dalam satu kubu. Turki ingin adanya pergantian rezim, sedangkan Rusia mendukung rezim pemerintahan Bashar al-Assad. Hubungan kedua negara juga diperburuk dengan penembakan jet Sukhoi-24 yang menyebabkan Rusia menerapkan sejumlah sanksi kepada Turki. Akan tetapi, sejak 2016 hingga 2019 tampak hubungan keduanya mulai membaik. Ini ditandai dengan berbagai kerja sama untuk mengakhiri perang saudara di Suriah. Berdasarkan teori balance of power dalam Hubungan Internasional, setiap negara berusaha untuk mencegah satu negara mendominasi. Intervensi militer yang dilakukan Rusia di Suriah pada 2015 dapat dianalisis sebagai upaya untuk mengubah perimbangan kekuatan global, sementara Turki dapat dikategorikan sebagai regional emerging power sehingga seharusnya Turkey menyeimbangkan kekuatan Rusia. Akan tetapi, keduanya justru bekerja sama. Dengan demikian pertanyaan penelitian yang diajukan dalam artikel ini: mengapa Turki memilih untuk bekerja sama dengan Rusia di Suriah pada periode tersebut? Untuk menjawab pertanyaan penelitian tersebut, peneliti akan menggunakan teori balance of interest dari Randall Schweller. Peneliti berargumen bahwa berubahnya orientasi kebijakan luar negeri Turki di masa AKP yang semakin keras terhadap Kurdi menyebabkan terjadinya gesekan dengan Amerika Serikat dan Eropa, sehingga Turki memilih menjalin hubungan strategis dengan Rusia untuk melawan kelompok Kurdi di Suriah.
\end{abstract}

Kata kunci: Turki, Rusia, Balance of Interest, Kebijakan Luar Negeri 


\section{PENDAHULUAN}

Pada awal pecahnya Musim Semi Arab di Suriah pada tahun 2011, Turki dan Rusia berada di pihak yang berseberangan. Turki ingin Presiden Suriah Bashar Al-Assad untuk menuruti permintaan rakyat dan melakukan reformasi. Namun, ketika permintaan ini ditolak Presiden Assad, Turki mulai mendukung oposisi dengan mempersenjatai dan melatih Free Syrian Army sambil menyambut lebih dari 2 juta pengungsi Suriah di wilayahnya. Di pihak lain, Rusia mendukung pemerintahan Presiden Assad dengan bantuan militer. Pada Oktober 2011, sebagai anggota tetap Dewan Keamanan PBB, Rusia melakukan veto draft resolusi yang menuntut lengsernya Presiden Assad. Di saat yang sama, hubungan Turki dan Rusia juga diperburuk oleh penembakan jet Sukhoi Su-24. Penembakan ini menyebabkan krisis politik dengan Moskow menerapkan sejumlah sanksi ekonomi terhadap Ankara (Tur, 2019).

Akan tetapi, sejak tahun 2016, hubungan Turki dan Rusia mulai menghangat yang salah satunya ditandai dengan kerja sama untuk mengakhiri Perang Saudara di Suriah. Melalui negosiasi Astana, Rusia, Turki, dan Iran mulai mengoordinasikan gencatan senjata bersama. Turki juga melakukan tiga operasi militer di bagian utara Suriah sejak tahun 2016 dengan izin Rusia. Pada Agustus 2018, Menteri Luar Negeri Rusia Sergei Lavrov mengatakan kedua negara akan mengabil langkah-langkah untuk meningkatkan kemitraan strategis. $\mathrm{Hal}$ senada juga diungkapkan Menteri Luar Negeri Turki Mevlut Cavusoglu yang menyebut Rusia sebagai mitra strategis bagi Turki (Kostem, 2020).

Kerja sama kedua negara tersebut memasuki babak baru pada 22 Oktober 2019 yang ditandai dengan bertemunya Presiden Turki Recep Tayyip Erdogan dan Presiden Rusia Vladimir Putin di resor Laut Hitam. Dalam pertemuan ini, keduanya sepakat untuk melakukan kerja sama di Suriah yang intinya berisikan upaya untuk mengamankan perbatasan Turki dan Suriah di bagian dari pasukan People's Protection Units (YPG) Kurdi. Pasukan YPG Kurdi harus mundur sejauh 30 kilometer dari perbatasan tersebut. Untuk pertama kali di wilayah bagian utara Suriah, Pasukan militer Turki dan Rusia pada 1 November 2019, memulai patroli bersama (Foreign Policy, 2019). Operasi militer ini disebut "Operation Peace Spring” (Hurriyet Daily News, 2019).

\section{TINJAUAN PUSTAKA}

Kajian terdahulu yang membahas kerja sama Turki dan Rusia di Suriah dapat dikelompokkan ke dalam dua perspektif besar yakni hubungan 
bilateral Turki dan Rusia, dan Kebijakan Luar Negeri Turki. Kajian hubungan bilateral Turki dan Rusia, berfokus pada kerja sama dan ketergantungan ekonomi kedua negara, kerja sama keamananan, dan kebutuhan Turki untuk melawan separatisme Kurdi.

Kesimpulan utama yang dapat ditarik dalam kajian hubungan bilateral Turki dan Rusia yaitu kerja sama Turki dan Russia dikarenakan adanya ketergantungan energi Turki terhadap Russia. Ini membuat Ankara sulit untuk menjauh dari Russia dan outputnya terlihat di bidang politik dan keamanan (Kardas, 2012; Warhola \& Bezei, 2013; Onis \& Yilmaz, 2015; Kostem, Seckin, 2018; Ozerdem, 2019). Sementara itu, dalam bidang keamanan kerja sama Turki dan Rusia di Suriah juga dapat disebut sebagai salah satu contoh dari assertive bandwagoning dan balance of threat untuk melawan separatisme Kurdi. Kerja sama kedua negara juga menyebabkan efek domino di sektor lain, namun kedekatan Turki dan Rusia tampaknya tidak akan berubah menjadi kemitraan keamanan yang dapat bertahan lama karena kedua negara kerap kali lebih memilih pilihan yang berbeda terkait konflik Suriah. Namun, keselarasan geopolitik Rusia-Turki memiliki implikasi yang signifikan bagi tatanan regional di era menurunnya pengaruh
Amerika Serikat di Timur Tengah (Didic \& Kosebalaban, 2019).

Sementara itu, peneliti pada kelompok kajian kebijakan luar negeri Turki menggunakan teori sekuritisasi (Kosebalaban, 2020). Kesimpulan utama yang dapat ditarik dalam kajian ini yakni sejak 2015, kebijakan luar negeri Turki secara bertahap telah bergerak menuju arah yang lebih nasionalis. Dalam konflik Suriah, Turki telah berpaling dari tujuan awalnya. Pada awalnya Turki membantu oposisi Assad, namun kini strategi yang Ankara terapkan bertujuan untuk melawan separatisme Kurdi. Transformasi orientasi strategis ini merupakan produk dari munculnya ancaman keamanan, serta perubahan politik dalam negeri termasuk sistem presidensial baru Turki (Kosebalaban, 2020).

Berdasarkan pemaparan kajian terdahulu di atas, meski peneliti mendapat berbagai pengetahuan yang cukup mendalam terkait kerja sama Turki dan Rusia di Suriah, peneliti juga menemukan kesenjangan. Intervensi militer yang dilakukan Rusia di Suriah pada 2015 dapat dianalisis sebagai upaya untuk mengubah perimbangan kekuatan global. Menurut Pieper (2019), kebijakan luar negeri Rusia di Suriah dapat disebut sebagai tindakan negara yang kekuatannya sedang meningkat. Hal ini ditunjukkan dengan berbagai tindakan Rusia seperti 
melakukan veto melawan resolusi damai Suriah yang diusulkan Barat, sementara intervensionisme sepihaknya dimaksudkan untuk secara bertahap menggeser margin sikap permisif perilaku negara. Di pihak lain, Turki juga dapat dikategorikan sebagai regional atau rising/ emerging power dalam beberapa dekade terakhir (Parlar Dal, 2015). Hal ini tampak dari upayanya dalam meningkatkan statusnya dalam tatanan internasional dan meluasnya lingkup multilateralismenya.

Berdasarkan teori balance of power dalam Hubungan Internasional, setiap negara baik itu sadar maupun tidak sadar berusaha untuk mencegah satu negara mendominasi (Kegley, Charles W.; Wittkopf, Eugene R, 2005; 503). Intervensi militer yang dilakukan Rusia di Suriah pada 2015 dapat dianalisis sebagai upaya untuk mengubah perimbangan kekuatan global, sementara Turki dapat dikategorikan sebagai regional atau rising/emerging power (Pieper, 2019; Parlar Dar, 2015). Dengan demikian pertanyaan penelitian yang diajukan dalam artikel ini: mengapa Turki memilih untuk bekerja sama dengan Rusia di Suriah pada periode 2016 hingga 2019?

Untuk menjawab pertanyaan penelitian tersebut, peneliti akan menggunakan neoklasikal realisme dan teori Balance of Interest dari Randall Schweller. Teori ini menjelaskan bagaimana suatu kebijakan luar negeri terbentuk dan bagaimana negara merespons peluang untuk mendapatkan keuntungan. Peneliti berargumen bahwa kerja sama Turki dan Rusia di Suriah pada periode 20162019 tidak bisa dilepaskan dari Kurdi Suriah yang dipersepsikan oleh The Justice and Development Party (AKP) sebagai ancaman terhadap kekuasaan partai dan Presiden Recep Tayyip Erdogan. Berubahnya orientasi kebijakan luar negeri Turki di masa AKP yang semakin keras terhadap Kurdi menyebabkan terjadinya ketidaksepahaman antara Turki dengan sekutu Baratnya yakni Amerika Serikat dan Eropa, sehingga Turki memilih menjalin hubungan strategis dengan Rusia untuk melawan kelompok Kurdi di Suriah.

Tulisan ini selanjutnya terbagi ke dalam lima bagian. Bagian pertama membahas kerangka analisis yang digunakan yakni teori Balance of Interest. Bagian kedua membahas metode penelitian kualitatif. Bagian ketiga membahas tekanan sistemik dan penghitungan kapabilitas Turki dan Rusia. Kemudian, bagian keempat memaparkan kepentingan Turki yang ditutup dengan simpulan.

\section{TEORI BALANCE OF INTEREST}

Dalam Ilmu Hubungan Internasional, alasan mengapa negara bekerja sama dapat dijelaskan dengan 
beberapa pendekatan. Tema yang diangkat dalam penelitian ini adalah kerja sama strategis Turki dan Rusia di Suriah pada periode 2016-2019. Dalam Ilmu Hubungan Internasional paradigma realisme merupakan pendekatan yang paling sering digunakan untuk menjelaskan kerja sama strategis antar negara dari sisi keamanan. Berdasarkan asumsi dasar realisme, isu yang penting dibahas dalam pendekatan ini adalah yang sifatnya high politics (keamanan dan militer). Paradigma realisme terbagi ke dalam beberapa pendekatan yakni classical realism, neorealism/structural realism, dan neoclassical realism. Dari ketiga pendekatan tersebut, yang sering digunakan untuk membahas aliansi negara yakni balance of power, balance of threat, dan balance of interest.

Menurut Kevin Sweeney dan Paul Fritz, teori balance of power dari pendekatan neorealisme yang dikemukakan oleh Kenneth Waltz hanya memberikan sedikit data empiris untuk mendukung argumennya mengenai balancing dan bandwagoning di antara negara-negara kuat (Sweeney \& Fritz, 2004: 429). Di sisi lain, Randall Schweller mengkritik Waltz yang menganggap semua great powers seperti unit. Dengan kata lain, bahwa perilaku negara semua sama (kapabilitas dan kepentingannya) (Schweller, 1998). Kemudian, teori balance of powver direvisi oleh Stephen M. Walt dengan menambahkan variabel lain yakni threat (ancaman) dan teorinya disebut balance of threat (BoT). Setelah itu, Randall Schweller melalui artikel jurnalnya yang berjudul "Bandwagoning for Profit: Bringing The Revisionist States Back In", mengkritik teori BoT melalui kerangka berpikir neoclassical realism. Schweller mengajukan teori yang bernama Balance of Interest (BoI) dengan menambahkan variabel lain yakni interest (kepentingan). BoI berupaya menjelaskan bagaimana negara merespons peluang untuk mendapatkan keuntungan (Schweller, 1994).

Artikel ini menggunakan teori balance of interest (BoI) dari pendekatan neoclassical realism karena teori ini mampu menjelaskan bagaimana distribusi kapabilitas dan kepentingan mempengaruhi kebijakan luar negeri suatu negara. Elemen penting dari teori ini adalah struktur sistem internasional dan kepentingan negara. Kekuatan relatif Great Powers menentukan struktur sistem internasional. Sementara itu, dalam tingkat unit, negara diidentifikasi menurut apakah negara tersebut puas dengan status-quo atau tidak. Dengan memasukkan unit dan kepentingan atau identitas mereka, stabilitas sistem dan perilaku negara dapat dijelaskan (Schweller, 1998).

Seperti yang telah disebutkan, BoI memiliki dua makna yakni di 
tataran unit dan di tataran sistem. Pada level unit, teori balance of interests mengacu pada biaya yang harus dibayar negara untuk mempertahankan nilai yang dimilikinya secara relatif, terhadap berapa banyak yang harus dibayar untuk memperbesar nilainya. Sementara pada level sistem mengacu pada seberapa kuat negara status-quo dan negara revisionis (Schweller, 1994).

Untuk menggunakan teori ini sebagai dasar analisis, pertama-tama yang harus dilakukan adalah mengetahui kapabilitas kekuatan negara sebagai dasar untuk menentukan posisi kepentingan negara atau sebagai variabel independen. Schweller dalam bukunya yang berjudul "Deadly Imbalances: Tripolarity and Hitler's Strategy of World Conquest" menjelaskan indikator-indikator untuk mengkategorisasikan tujuan dan perilaku negara dengan melihat kapabilitas kekuatan dan kepentingan negara tersebut. Kapabilitas kekuatan negara perlu dilihat untuk mengetahui posisi negara apakah negara tersebut negara poles atau lesser great powers (LGP) (Schweller, 1998).

Schweller menjelaskan, suatu negara dapat disebut negara pole apabila negara tersebut memiliki kapabilitas militer lebih besar dari setengah kapabilitas militer yang dimiliki negara-negara kuat dalam sistem, sementara negara kuat lainnya disebut LGP. Poles adalah Great Powers peringkat pertama. LGP adalah adalah Great Powers peringkat kedua. LGP memiliki kekuatan militer yang cukup besar. Namun, tidak seperti negara kecil atau middle powers, LGP memiliki pengaruh yang signifikan dalam global dan regional balance of power dengan cara membuat sistem stabil ketika disekuilibrium atau ketika polar balance muncul, LGP memainkan peran sebagai kingmaker dengan mendukung salah satu koalisi. Setelah mengkategorisasikan negara, kemudian melihat kepentingan negara sebagai variable intervening. Setelah mengetahui kapabilitas masing-masing negara, negara dapat dikategorisasikan sesuai dengan kepentingannya untuk mengetahui apakah negara tersebut status quo atau revisionis. Dari sini dapat dilihat alasan mengapa negara mengambil suatu kebijakan tertentu (Ibid.).

Bagan 1: Model Analisis

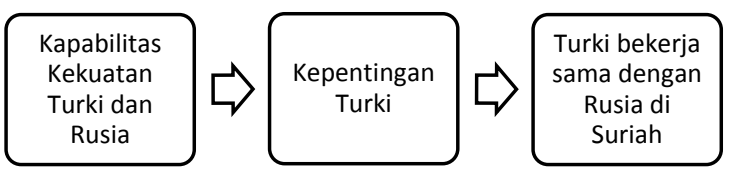

\section{METODE PENELITIAN}

Dalam penelitian ini, peneliti menggunakan metode penelitian kualitatif dengan pendekatan deduktif untuk secara sistematis, faktual, dan akurat memahami isu yang diteliti. 
Penelitian kualitatif dapat didefinisikan sebagai penelitian untuk memahami fenomena yang dialami oleh suatu objek penelitian. Sementara itu, terkait pengumpulan data yang dilakukan adalah dengan penelusuran data sekunder yang diperoleh dari artikel akademik, buku akademik, media daring, dan situs resmi pemerintah. Pengumpulan data dilakukan untuk membangun pemahanan dasar tentang kerja sama Turki dan Rusia serta kepentingan strategis apa yang membuat keduanya sepakat bekerja sama di Suriah.

\section{TEKANAN SISTEMIK DAN TIPOLOGI TURKI}

Untuk menjelaskan perubahan kekuatan relatif dalam struktur regional yang memengaruhi Turki, terdapat tiga faktor yang mewakili kondisi tersebut. Faktor pertama yakni menurunnya hegemoni Amerika Serikat yang ditandai dengan meningkatnya kekuatan Tiongkok sebagai kekuatan ekonomi dunia (Sahide, 2021: 13). Faktor kedua yakni ketidakstabilan politik Timur Tengah setelah pecahnya Musim Semi Arab yang menyebabkan terjadinya perebutan kekuasaan dan fragmentasi sektarian intra dan antar negara di wilayah Timur Tengah dan Afrika Utara serta munculnya aktor nonnegara (kelompok ekstremis) yang menguasai wilayah yang tidak stabil akibat kekosongan pemerintahan (Yorulmazlar \& Ebru Turhan, 2015: 7). Faktor ketiga yakni meningkatnya pengaruh Rusia di kawasan tersebut setelah cukup lama absen (Dannreuthera , 2014).

Menurunnya hegemoni Amerika Serikat (AS) di kawasan Timur Tengah membuat kekuatan regional melakukan berbagai manuver politik untuk membangun sebuah tata dunia baru sesuai dengan visi mereka masing-masing. Turki melihat hal ini sebagai sebuah kesempatan untuk menyebarkan pengaruhnya. Akan tetapi, karena pergolakan ini juga menyebabkan kekacauan, muncul pula berbagai hal yang dilihat sebagai ancaman bagi Turki (Aras, 2011; Aras, 2014).

Perubahan geopolitik Timur Tengah akibat Musim Semi Arab membuat Turki mengevaluasi kembali strategi diplomatik regionalnya. Sementara hegemoni Amerika Serikat mengalami penurunan, kekuatan regional seperti Iran dan Arab Saudi mulai mengeksploitasi hal tersebut untuk mengejar visi mereka sendiri. Semakin dalamnya isu sektarian antara Sunni yang dipimpin oleh Arab Saudi bersama dengan negara anggota Gulf Cooperation Council (GCC) dan Syiah yang dipimpin oleh Iran, turut melemahkan tatanan Kawasan (Yorulmazlar \& Ebru Turhan, 2015: 7). 
Krisis Suriah, perang di Yaman, dan meningkatnya ekstrimisme kelompok Islam yang berkembang di Timur Tengah akibat ketidakstabilan Kawasan pasca pergolakan membuat Turki kewalahan sehingga mencari alternatif-alternatif lain. Upaya bersama Barat (Amerika Serikat dan Uni Eropa) dan Turki terhambat oleh melemahnya dialog politik Turki dengan Unie Eropa, yang menyebabkan kurangnya komunikasi antara kedua pihak mengenai preferensi dan kepentingan mereka terkait Timur Tengah. Meningkatnya persaingan regional disertai dengan perebutan kekuasaan yang berkelanjutan dalam lanskap geopolitik pasca-Musim Semi Arab semakin memperumit hubungan Barat-Turki (Yorulmazlar \& Ebru Turhan, 2015: 7).

Hal itu pula yang kemudian membuat Ankara mencari alternatif lain yang berujung pada kerja sama antara Rusia, Turki, dan Iran. Ketiga negara itu pada akhirnya mengesampingkan perbedaan geopolitik mereka dengan bekerja sama demi menjaga kepentingan nasional, serta keamanan dan stabilitas regional (Joobani \& Mousavipur, 2015).

Terkait meningkatnya pengaruh Rusia di Timur Tengah, Moskow telah melakukan upaya strategis untuk memperluas dan meningkatkan pengaruhnya di Timur Tengah. Rusia menggunakan penjualan senjata, penjualan atau pembelian energi, dan dukungan diplomatik untuk mendapatkan posisi dan menyebarkan pengaruhnya di Kawasan Timur Tengah (Stepanova, 2018).

Dengan menggunakan kerangka analisis teori balance of interest, terdapat sejumlah temuan yang menarik. Di bawah ini adalah pemaparan analisis penghitungan kapabilitas negara (power) yang digunakan untuk mengkategorisasikan negara sesuai dengan kategori Schweller di dalam buku Deadly Imbalances: Tripolarity and Hitler's Strategy of World Conquest. Terdapat dua negara yang dianalisis yakni: Turki dan Rusia. Turki adalah negara yang menjadi fokus utama dalam penelitian ini. Sementara itu, Rusia adalah negara yang memiliki signifikansi besar di Suriah. Hasil penghitungan di bawah ini kemudian akan dihubungkan dengan kepentingan Turki dalam melakukan kerja sama dengan Rusia.

Penghitungan yang peneliti lakukan menggunakan data dari Correlates of War sama seperti penghitungan yang dilakukan Schweller. Karena data dari Correlates of War V5.0 hanya sampai tahun 2012, peneliti mengambil data dari tahun tersebut. Berikut hasil penghitungannya. 
Tabel 1: Penghitungan Kekuatan Turki dan Rusia

\begin{tabular}{|c|c|c|c|c|c|c|}
\hline & \multicolumn{2}{|c|}{ Military Strength } & \multicolumn{2}{c|}{ Economic Strength } & \multicolumn{2}{c|}{ Demograpic } \\
\hline Negara & Personnel & Expenditure & $\begin{array}{c}\text { Energy } \\
\text { Consumption }\end{array}$ & $\begin{array}{c}\text { Iron \&Steel } \\
\text { Production }\end{array}$ & $\begin{array}{c}\text { Urban } \\
\text { population }\end{array}$ & $\begin{array}{c}\text { Total } \\
\text { population }\end{array}$ \\
\hline Turki & $16.83 \%$ & $1.4 \%$ & $3.85 \%$ & $18.42 \%$ & $13.33 \%$ & $13.83 \%$ \\
\hline Rusia & $31.48 \%$ & $8.11 \%$ & $28.88 \%$ & $36.04 \%$ & $19.56 \%$ & $26.77 \%$ \\
\hline
\end{tabular}

Sumber: Correlates of War V5.0

Tabel 2: Kategori Ketiga Negara berdasarkan Teori Balance of Interest

\begin{tabular}{|c|c|c|c|}
\hline Negara & Overall Strength & Relative Strength (skor) & Kategori \\
\hline Turki & 11.27 & 2,24 & LGP \\
\hline Rusia & 25.14 & 5 & Poles \\
\hline
\end{tabular}

Berdasarkan hasil perhitungan power ketiga negara tersebut, dapat dilihat bahwa Rusia merupakan negara dengan power yang besar dan dapat dikategorikan sebagai poles. Sementara itu, Turki memiliki power yang lebih sedikit dibandingkan dengan kedua negara lainnya sehingga dikategorikan sebagai LGP. Kemudian, nilai power tersebut dikonversi menjadi skor 1-5 seperti yang dilakukan oleh Schweller untuk mengkategorikan tipe masingmasing negara.

Turki adalah negara dengan skor 2,24 merupakan LGP. Dari pembahasan sebelumnya, Turki tampaknya memiliki karakter "agresif" serta memiliki kepentingan utama untuk mempertahankan keamanan nasionalnya. Hal ini dapat dilihat dari keputusannya untuk menginvasi Suriah bagian utara setelah AS memutuskan untuk menarik pasukannya, dan melakukan patroli bersama dengan Rusia. Oleh karena itu, Turki untuk kasus di Suriah ini cenderung pro revisionis selama hal tersebut menjamin keamanan nasional Turki. Dari dua pilihan kategori negara yang dapat diberikan, jackal adalah yang paling cocok.

Di sisi lain, Rusia adalah negara besar lainnya yang ingin meningkatkan kembali pengaruhnya di kawasan Timur Tengah, khususnya dengan penggunaan hard power dan soft power. Hal tersebut antara lain diperlihatkan dengan adanya pendirian dua pangkalan militer Rusia permanen di Suriah, dan secara bersamaan menggunakan soft power yakni inisiatif diplomatik (Astana-Sochi) (Kostelyanets, 2019). Dengan poin 5 Rusia adalah negara poles yang condong ke arah revisionis lantaran Rusia kerap berseberangan dengan Amerika Serikat dan Barat.

\section{Kepentingan Turki dalam Kerja Sama dengan Rusia di Suriah}


Dari hasil kategorisasi negaranegara di atas, analisis terhadap kebijakan keamanan Turki terhadap Rusia dapat dilakukan dengan dasar yang lebih kuat. Bagian ini menganalisis kebijakan kerja sama keamanan Turki sebagai negara LGP terhadap Rusia sebagai negara poles dalam konflik Suriah. Turki sebagai negara LGP yang memiliki kepentingan di kawasan Timur Tengah melakukan kebijakan bandwagoning dengan Rusia. Hal ini dikarenakan pecahnya Musim Semi Arab yang melebar hingga ke Suriah membuat hubungan Turki dan sekutu Baratnya yakni Amerika Serikat dan The North Atlantic Treaty Organization (NATO) mulai retak. Kepentingan Turki dan sekutu Baratnya berbenturan karena Ankara lebih berfokus pada berperang melawan Kurdi Suriah, sedangkan Amerika Serikat lebih berfokus pada berperang melawan kelompok teroris Islamic State (IS). Turki menilai milisi dalam aliansi pimpinan Kurdi yang berperang di Suriah merupakan organisasi teroris, perpanjangan dari kelompok pemberontak Kurdi yang selama puluhan tahun memberontak di Turki (BBC, 2019). Bangsa Kurdi yang menguasai wilayah Suriah bagian Utara yang begitu dekat dengan perbatasan Turki dinilai sebagai ancaman keamanan nasional utama lantaran khawatir bahwa wilayah itu bisa menjadi surga bagi para pemberontak
Kurdi yang melarikan diri dari Turki atau batu loncatan bagi pemberontak yang merencanakan serangan di wilayah Turki (New York Times, 2019). Di dalam negeri Turki berupaya untuk menangani masalah PKK dan secara regional Kurdi Suriah adalah isu Rusia yang harus diselesaikan dengan rezim di Suriah (Zahra, 2017: 5). Fokus Turki dalam berperang melawan Kurdi ini membawanya lebih dekat dengan Rusia sehingga kebijakannya mengalami perubahan yang signifikan (Yücesoy, V, 2019).

Sejak 2016, Turki melakukan bandwagoning dengan Rusia yakni tipe piling on bandwagoning dan jackal bandwagoning yang disebabkan oleh Kurdi Suriah (YPG/PYD). Kelompok Kurdi Suriah tersebut merupakan afiliasi Partiya Karkere $n$ Kurdistan (PKK) yang dianggap oleh AKP sebagai ancaman terhadap stabilitas keamanan nasional Turki (Wei, 2019). Menurut Schweller, piling on bandwagoning terjadi ketika hasil perang telah terlihat. Negara biasanya akan melakukan bandwagon dengan pihak yang menang untuk memperoleh keuntungan. Ketika ini adalah motifnya, piling on bandwagoning adalah jackal bandwagoning yang terjadi di akhir perang (Schweller, 1998). Turki mengubah kebijakan luar negerinya secara signifikan setelah tahun 2016. Perubahan ini dipicu oleh Turki yang sadar akan batas kekuatannya. 
Di Suriah, Turki menyadari bahwa tidak hanya kalah dalam pertempuran menggulingkan Assad, tetapi juga menghadapi gelombang nasionalisme Kurdi yang meningkat di kawasan tersebut. Turki pun akhirnya tidak lagi mengedepankan perubahan rezim di Suriah. Di saat yang hampir bersamaan, setelah percobaan gagal kudeta di Juli 2016, Presiden Erdogan bersama dengan partainya, AKP, mengubah kebijakan hubungan internasional termasuk aliansi Turki. Kebijakan luar negeri Turki setelah kudeta gagal ini dapat disebut sebagai kebijakan appeasement untuk melawan ancaman eksternal dan melawan musuh domestik AKP, yakni PKK. Oleh karena itu, pembuatan kebijakan luar negeri Turki menjadi didasarkan pada upaya melawan ancaman domestik. Pada 20 Agustus 2016, Turki secara resmi mengumumkan kebijakan baru yang bertujuan untuk menyelesaikan krisis dengan melibatkan semua aktor kunci, termasuk Presiden Suriah Bashar alAssad (Yucesov, 2019). Hal ini kemudian merefleksikan hubungan Turki dan Rusia yang kian erat.

Pada Desember 2016, Turki, dan Rusia bersama Iran sepakat untuk menciptakan zona 'de-eskalasi' di Suriah, yang menguntungkan rezim Assad. Hingga 2019 hubungan Ankara dan Moskow masih dekat. Setelah Amerika Serikat memutuskan untuk menarik pasukannya di Suriah bagian utara, Turki bersama dengan Rusia melakukan patroli bersama di wilayah tersebut, di mana ini merupakan pertama kalinya dalam sejarah kedua negara tersebut (CNN). Upaya patroli tersebut merupakan bentuk jackal bandwagoning. Menurut Schweller, lesser aggresor mencapai kesepakatan dengan pemimpin revisionis untuk menyebarkan pengaruhnya, dan junior partner ini akan mendukung pemimpin revisionis dalam tujuannya untuk berekspansi (Schweller, 1998). Turki yang dapat dikatakan sebagai lesser aggresor di sini mencapai kesepakatan dengan Rusia untuk melakukan patroli bersama di Suriah bagian utara guna mengamankan perbatasan Turki dan Suriah di bagian dari pasukan Kurdi Suriah yakni YPG. Inti dari kesepakatan tersebut adalah pasukan Kurdi YPG harus mundur sejauh 30 kilometer dari perbatasan tersebut (Foreign Policy, 2019). Kurdi Suriah (PYD/YPG) yang merupakan afiliasi PKK dianggap sebagai ancaman terhadap stabilitas nasional Turki. Turki menginginkan perbatasan yang lebih aman, serta pengaruh politik dan strategis yang lebih besar di Suriah bagian utara. Hal ini dikarenakan AKP dan Presiden Erdogan, ingin mempertahankan kekuasaannya dengan cara memerangi ancaman eksternal yang mereka persepsikan 
sebagai ancaman atas kepimpinan partai.

Selain itu dalam konteks pasca2016, Rusia tidak lagi dipandang sebagai ancaman utama terhadap keamanan nasional Turki. Kehadiran milisi Kurdi di bagian utara Suriah yang berbatasan langsung dengan Turki kini menjadi fokus keamanan nasional yang membuatnya ingin membinasakan kelompok itu. Keinginan ini terwujud dalam pengepungan Turki tahun 2018 di kota Afrin, Suriah, sebagaimana disebutkan oleh Erdogan, karena wilayah Suriah sekarang didominasi Rusia, mereka membutuhkan izin dari Moskow. Persetujuan Rusia dalam operasi militer Turki itu menandakan perbedaan dari sikap sebelumnya di mana Rusia melarang tindakan sepihak Turki di wilayah Suriah. Dengan demikian, Turki menjalin hubungan lebih dekat dengan Rusia untuk melakukan ofensif vis-à-vis terhadap Kurdi Suriah (Đidić \& Kösebalaban, 2019: 11).

Invasi Turki ke bagian Utara Suriah bukannya tanpa kecaman. Meskipun Amerika Serikat mengecam invasi ini karena Kurdi Suriah merupakan sekutunya baik itu selama Perang Saudara Suriah, perang melawan kelompok teroris ISIS maupun perang melawan rezim Bashar Al-Assad, Turki tetap melakukan serangan di Suriah bagian Utara yang diduduki oleh Kurdi dan melakukan kerja sama keamanan dengan Rusia untuk melawan Kurdi yang dilabeli sebagai teroris oleh Pemerintah Turki (The Guardian , 2019; Reuters, 2019; BBC, 2019). Bahkan, Presiden Erdogan mengatakan bahwa ia tidak akan menghentikan serangannya kepada para pejuang Kurdi, tidak peduli apa kata orang (BBC, 2019). Hal ini menunjukkan bahwa melawan Kurdi adalah prioritas dan ia tidak peduli meskipun mendapat kecaman dari berbagai pihak karena Kurdi mereka anggap sebagai teroris.

AS pada 15 Oktober 2019 menjatuhkan sanksi pada Turki. Pada 23 Oktober 2019, Presiden Putin dan Presiden Erdogan mengumumkan kesepakatan gencatan senjata untuk Suriah utara. Perjanjian tersebut meletakkan dasar untuk memperluas kekuasaan Bashar al-Assad di Suriah bagian timur laut, mengamankan kehadiran militer Rusia di Suriah, dan meresmikan penyebaran militer Turki di wilayah yang dekat dengan perbatasan utara (Ecfr, 2019). Hal ini sesuai dengan teori Balance of Interest bahwa lesser aggresor dalam hal ini Turki mencapai kesepakatan dengan pemimpin revisionis yakni Rusia untuk menyebarkan pengaruhnya, dan junior partner ini akan mendukung pemimpin revisionis dalam tujuannya untuk berekspansi. 
Dari pemaparan di atas dapat dilihat bahwa isu Suriah menyebabkan hubungan Turki dengan sekutu Baratnya menegang, sehingga Ankara menjadi semakin terisolasi. Di saat yang bersamaan Turki juga menghabiskan sumber dayanya untuk mengatasi gelombang besar pengungsi Suriah yang melarikan diri ke Turki. Akibatnya, Turki tidak dapat melanjutkan kebijakan perubahan rezim yang menjadi landasan kebijakan luar negerinya di Suriah. Amerika Serikat dan sekutu Baratnya meninggalkan Turki demi kalkulasi realpolitik mereka (Didic \& Kosebalaban, 2019). Pada saat yang sama, karena keterlibatan Rusia dan Iran, Ankara melihat kesempatan untuk bekerja sama dengan kedua negara tersebut demi mencapai tujuan nasionalnya (Joobani \& Mousavipour, 2015). Dengan Kurdi Suriah didukung oleh AS, Turki melihat peluang kerja sama strategis dengan Rusia. Persepsi Turki yang menganggap Kurdi di Suriah sebagai ancaman menjelaskan piling on bandwagoning dan jackal bandwagoning Turki dengan Rusia. Politik domestik Turki berperan sangat dominan dalam fenomena ini yakni kepemimpinan AKP yang semakin otoritarian. Kelompok Kurdi di Suriah yang dianggap sebagai kelompok yang terkait dengan PKK, membuatnya menjadi lebih dekat ke Rusia untuk mendapatkan izin melakukan operasi militer.

\section{SIMPULAN}

Berdasarkan penjelasanpenjelasan di atas, dapat disimpulkan bahwa pendekatan Turki dengan Rusia di bidang kerja sama keamanan adalah respons terhadap relative power dan juga karena adanya dorongan dari politik nasional Turki. Rusia dapat disebut sebagai negara great power peringkat pertama karena hasil dari perhitungan kekuatannya memperoleh skor 5 . Sementara itu, Turki merupakan lesser great power karena memiliki skor 2,26.

Kerja sama keamanan antara Turki dengan Rusia di Suriah awalnya dimulai dengan kesadaran Turki akan keterbatasan kekuatannya dan kudeta gagal di 2016 yang membuatnya terisolasi dari sekutu baratnya, yakni Amerika Serikat. Pasalnya, setelah kudeta gagal ini Partai AKP melakukan penangkapan besar-besaran terhadap lawan politiknya dan melakukan pelanggaran HAM, di mana ini membuat sekutu baratnya mengutuk tindakan Turki ini.

Hubungan kerja sama keamanan antara Turki dengan Rusia yang dapat dinilai sebagai perilaku bandwagoning ini didorong utamanya oleh politik domestik Turki, di mana AKP menganggap kelompok Kurdi Suriah yakni PYD dan juga YPG sebagai 
ancaman karena kedua kelompok ini merupakan afiliasi PKK yang dilabeli oleh Turki sebagai organisasi teroris. Kelompok Kurdi Suriah menguasai wilayah Suriah bagian utara yang berbatasan langsung dengan Turki, sehingga Kurdi Suriah dianggap sebagai ancaman terhadap stabilitas nasional Turki.

Sejak 2016, kebijakan luar negeri Turki terhadap Suriah berubah secara signifikan dan berfokus pada mempertahankan kekuasaan AKP dan Presiden Erdogan. Dengan demikian, invasi Turki ke Suriah bagian Utara pada Oktober 2019 lalu dapat dipahami sebagai keinginan Turki untuk memiliki perbatasan yang lebih aman, dengan cara memperbesar pengaruh politik dan strategis yang lebih besar di Suriah bagian utara. AKP dan Presiden Erdogan, ingin mempertahankan kekuasaannya dengan cara memerangi ancaman eksternal yang mereka persepsikan sebagai ancaman atas kepimpinan partai. Hal ini yang membuat Turki mendekat dengan Rusia.

Kedekatan Turki dengan Rusia dapat dijelaskan dengan teori balance of interest. Hasil dari perhitungan kapabilitas kekuatan Turki dan Rusia menunjukkan bahwa Turki merupakan negara lesser great power. Sementara Rusia adalah negara poles. Turki memiliki karakter agresif dan memiliki kepentingan utama untuk mempertahankan keberlangsungan kekuasaan partai. Hal ini dapat dilihat dari keputusannya untuk menginvasi Suriah bagian utara setelah AS memutuskan untuk menarik pasukannya, dan melakukan patroli bersama dengan Rusia.

Oleh karena itu, Turki cenderung pro revisionis selama hal tersebut menjamin keamanan nasionalnya. Terkait hubungan Turki dengan Amerika Serikat, perbedaan pandangan terkait Kurdi membuat hubungan keduanya merenggang. Persepsi Turki yang menganggap Kurdi di Suriah sebagai ancaman menjelaskan piling on bandwagoning dan jackal bandwagoning Turki dengan Rusia. Politik domestik Turki berperan sangat dominan dalam fenomena ini yakni kepemimpinan AKP yang semakin otoritarian. Dengan demikian, pendekatan kembali kerja sama keamanan antara Turki dengan Rusia disebabkan oleh kepentingan domestik Turki yakni AKP melihat kesempatan untuk memperoleh keuntungan. Keuntungan yang dimaksud adalah melanggengkan kekuasaan AKP di perpolitikan nasional Turki.

\section{REFERENSI}

Aljazeera. (2019) Russia and Turkey: Partners or opponents in Syria? (Online). Retrieved from: https://www.aljazeera.com/news/201 9/10/russia-turkey-partnersopponents-syria- 
191022111531956.html (Accessed:

December 2020).

Al-Monitor. (2016) Erdogan's Syria policy hits dead end in Aleppo (Online). Retrieved from: http://www.almonitor.com/pulse/originals/2016/12 /erdogan-syria-policy-turkey-deadend-aleppo.html (Accessed: December 2020).

Aras, B. \&. (2011) "Turkey and the Arab Spring”. International Journal, 3940.

Aras, B., \& Yorulmazlar, E. (2014) "Turkey and Iran After The Arab Spring: Finding a Middle Ground". Middle East Policy, XXI(4).

Barkey, H. J. (2014) “Turkey’s Syria Predicament”. Survival. 56(6), 113134.

BBC News. (2016) Turkey sends tanks into Syria to battle ISIS (Online). Retrieved from: https://edition.cnn.com/2016/08/24/ middleeast/turkish-troops-isis-syriaoperation (Accessed: December 2020).

BBC News. (2019) Turkey Syria offensive: Erdogan and Putin strike deal over Kurds (Online). Retrieved from: https://www.bbc.com/news/worldmiddle-east-50138121 (Accessed: December 2020).

BBC News. (2019) Turkey-Syria offensive: US sanctions Turkish ministries (Online). Retrieved from: https://www.bbc.com/news/worldmiddle-east-50050264 (Accessed: December 2020).

Dannreuther, R. (2014) "Russia and the Arab Spring: Supporting the Counter-Revolution" Journal of European Integration, 37(1), 77-94.

Dar, E. P. (2016) "Conceptualising and Testing the 'Emerging Regional Power' of Turkey in the Shifting
International Order". Third World Quarterly, 37(8), 1425-1453.

Demirtas-Bagdonas, Ö. (2014) "Reading Turkey's Foreign Policy on Syria: The AKP's Construction of a Great Power Identity and the Politics of Grandeur". Turkish Studies, 15(1), 139-155.

Đidić, A. \&. (2019) “Turkey’s Rapprochement with Russia: Assertive Bandwagoning". The International Spectator, 54(3), 123138.

ECFR EU. (2019) Managed chaos: Russia's deal with Turkey on northern Syria (Online). Retrieved from: https://www.ecfr.eu/article/comment ary_managed_chaos_russias_deal_w ith_turkey_on_northern_syria (Accessed: December 2020).

Esen, B., \& Gumuscu, S. (2016) "Rising competitive authoritarianism in Turkey". Third World Quarterly, 37(9), 1581-1606.

Foreign Policy. (2019) Kurds Lose Again as Russia Brokers New Deal (Online). Retrieved from: https://foreignpolicy.com/2019/10/2 2/fighting-continues-syria-turkeysdf-claim-territory (Accessed: December 2020).

France24. (2016) Erdogan says Syria Operation Aimed at IS jihadists, Kurdish PYD (Online). Retrieved from:

http://www.france24.com/en/201608 24-erdogan-says-syria-operationaimed-jihadists-kurdish-pyd (Accessed: December 2020).

Hurrydailynews. (2016) Turkey entered Syria to end al-Assad's rule: President Erdoğan. (2016). Retrieved from: http://www.hurriyetdailynews.com/t urkey-entered-syria-to-end-al- 
assads-rule-president-

erdogan. aspx?PageID=238\&NID $=10$

6709\&NewsCatID=352 (Accessed:

December 2020).

Hurrydailynews. (2019) Turkey, Russia agree on new Syria accord" (Online). Retrieved from: http://www.hurriyetdailynews.com/t urkey-russia-agree-on-new-syriaaccord-147836 (Accessed: December 2020).

Joobani, H \& Mousavipour, M. (2015) "Russia, Turkey, and Iran: Moving Towards Strategic Synergy in the Middle East?". Strategic Analysis. 39(2), pp. 141-155.

Kegley, C. W., \& Wittkopf, E. R. (2005). World Politics: Trends and Transformation.

Kösebalaban, H. (2020) “Transformation of Turkish Foreign Policy Toward Syria: The Return of Securitization". Middle East Critics, 29(3), 335-344.

Kostelyanets, S. V. (2019) "Russia's Peace Initiatives in the MENA Region: Evaluation and Prospects". Asian Journal of Middle Eastern and Islamic Studies.

Köstem, S. (2020) "Russian-Turkish Cooperation in Syria: Geopolitical Alignment with Limits". Cambridge Review of International Affairs.

Litsas, S. (2014) "Bandwagoning for profit and Turkey: Alliance Form". Israel Affairs, 20(1), 125-139.

Lobell, S. E. (2009) Neoclassical Realism, the State, and Foreign Policy. Cambridge: Cambridge University Press.

Pieper, M. (2019) “'Rising Power' Status and the Evolution of International Order: Conceptualising Russia's Syria Policies". Europe-Asia Studies, 71(3), 365-387.
Reuters. (2019) U.S. military says not abandoning Kurds, condemns Turkish Offensive (Online). Retrieved from: https://www.reuters.com/article/ussyria-security-turkey-usapentagon/us-military-says-notabandoning-kurds-condemnsturkish-offensive-idUSKBN1WQ29J (Accessed: December 2020).

Sahide, A. (2021) Proteksionisme Trump dan Masa Depan Supremasi Politik AS. Jurnal Ilmiah Hubungan Internasional. Vol. 17, No. 1.

Schweller, R. (1994) "Bandwagoning for Profit: Bringing the Revisionist State Back In". International Security, 19(1), 71-107.

Schweller, R. (1998) Deadly Imbalances: Tripolarity and Hitler's Strategy of World Conquest. New York: Columbia University Press.

Schweller, R. (2006) Unaswered Threats: Political Constraints on the Balance of Power. Princeton University Press.

Stepanova, E. (2018) "Russia and Conflicts in the Middle East: Regionalisation and Implications for the West". The International Spectator, 1-23.

Svarin, D. (2015) "Towards a Eurasian Axis? Russia and Turkey between Cooperation and Competition". Global Affairs, 1(4-5), 381-398.

Sweeney, K. \&. (2004) "Jumping on the Bandwagon: An Interest-Based Explanation for Great Power Alliances". The Journal of Politics, 66(2), 428-449.

The Guardian. (2019) Turkey unleashes airstrikes against Kurds in northeast Syria. (Onlien). Retrieved from: https://www.theguardian.com/world/ 2019/oct/09/turkey-launchesmilitary-operation-in-northern-syria- 
erdogan (Accessed: December 2020).

Tür, Ö. (2019) “Turkey’s Role in Middle East and Gulf Security". Asian Journal of Middle Eastern and Islamic Studies, 1-12.

Wei, M. (2019) “Turkish Foreign Policy Towards the Syrian Crisis: Dynamics of Transformation". Asian Journal of Middle Eastern and Islamic Studies.

Yorulmazlar, E., \& Turhan, E. (2015) "Turkish Foreign Policy towards the Arab Spring: Between Western Orientation and Regional Disorder". Journal of Balkan and Near Eastern Studies, 17(3).
Yücesoy, V. (2019) "The recent Rapprochement between Iran and Turkey: Is It Durable or Is it a Relationship of Convenience?". Turkish Studies.

Zahra, R. F. (2017) "Securitization and De-securitization: Turkey-Syria Relations since the Syrian Crisis". Asian Journal of Middle Eastern and Islamic Studies, 11(2), 27-39.

Zanotti, J. (2011) 'Turkey-U.S. Defense Cooperation: Prospects and Challenges'. Congressional Research Service 7-5700 www.crs.gov R41761, 2-3. 